\title{
In Vitro Metabolism of Tryptophan by Ruminal \\ Protozoa and Bacteria: The Production of \\ Indole and Skatole and their Effects on \\ Protozoal Survival and VFA Production
}

\author{
Ryoji Onodera, Hiroshi Ueda*, Takashi Nagasawa, \\ Katsuya OKuUchI, Shigehiro $\mathrm{CHAEN}^{* *}$, \\ Michitaka MiENo** and Hidehiko Kudo*** \\ Faculty of Agriculture, Miyazaki University \\ Miyazaki-shi 889-21
}

(Received July 3, 1991)

\begin{abstract}
An in vitro study was conducted to confirm the production of indole (Ind) and skatole (Skt) from L tryptophan ( $\mathrm{Trp}$ ) by mixed rumen protozoa (P suspensions), mixed rumen bacteria (B suspensions) and their combinatorn (BP suspensions), and to examine the effects of salinomycin (SL) on the production of Ind and Skt from Trp by those microorganisms. The effects of Ind and Skt on the survival of protozoa and the production of volatile fatty acids (VFA) by those microorganisms were also examined. Rumen microorganisms were collected from a fistulated goat. P suspensions produced only Ind from Trp during a 12-h incubation period. SL stimulated the production of Ind by $\mathrm{P}$ suspensions. Both $\mathrm{B}$ and $\mathrm{BP}$ suspensions produced Skt and Ind. SL almost completely inhibited the production of Skt and Ind by those microbial suspensions. Low concentrations of Ind and Skt (2 $\mathrm{mM})$ kept protozoa alive in BP suspensions for a long time, stimulated the total VFA production in B and BP suspensions, and increased the molar percentages of propionate and butyrate in BP suspensions.
\end{abstract}

Anim. Sci. Technol. (Jpn.) 63 (1):23-31, 1992

Key words : rumen microorganisms, tryptophan metabolism, indole, skatole, salinomycin

Ever since 3-methylindole (skatole) was specified as a causative factor of tryptophaninduced pulmonary edema and emphysema in cattle and goats by CARLSON et al. ${ }^{5)}$, tryptophan metabolism by rumen microorganisms has been studied in detail mainly by CARLSON and his co-workers. A tentative pathway for the fermentation of L-tryptophan by mixed rumen microorganisms in vitro was shown by Yokoyama and Carlson ${ }^{18)}$. They showed, using cheese-cloth strained rumen contents from steers maintained on an alfalfa-grass hay diet, that $39 \%$ of the initial radioactivity of the added $\mathrm{L}-\left[\mathrm{U}\right.$-benzen ring $\left.-{ }^{14} \mathrm{C}\right]$ tryptophan was incorporated into skatole, $7 \%$ into indole and $4 \%$ into indoleacetate after incubation for

Preset address :

* Taiho Pharmaceutical Co., Ltd., Tokushima-shi 771-01

** Showa Denko Co., Ltd., Minato-ku, Tokyo 105

*** Kaken Pharmaceutical Co Ltd, Chuo-ku, Tokyo 103

Anim. Sci. Technol. (Jpn.) 63 (1) : 23-31 
$24 \mathrm{~h}$, and that $38 \%$ of the initial radioactivity of the added $\left[2-{ }^{14} \mathrm{C}\right]$ indoleacetate was incorporated into skatole during a $24-\mathrm{h}$ incubation period. They thought, therefore, that the main path for the formation of skatole from L-tryptophan was by a two-step process involving the initial formation of indoleacetate from tryptophan and the subsequent decarboxylation of indoleacetate to skatole. However, they omitted describing that indole formation might probably be due to the tryptophanase in rumen microbes, as shown in other tryptophanase $e^{3,9)}$, and the tentative pathway they offered for the fermentation of L-tryptophan and related indolic compounds by ruminal microorganisms in vitro did not include the path for the formation of indole by tryptophanase. Their results also showed that incubation of the same ${ }^{14} \mathrm{C}$-labelled tryptophan with ruminal fluid freed of protozoa for $24 \mathrm{~h}$ resulted in $50 \%$ incorporation into indoleacetate, $13 \%$ into skatole and $4 \%$ into indole, while incubation of the same radioactive compound with a crude preparation of ruminal protozoa for $24 \mathrm{~h}$ resulted in $8 \%$ of the added radioactivity incorporated into indoleacetate, $3 \%$ into indole and only $0.1 \%$ into skatole. They also mentioned that the bacterial population of ruminal fluid was responsible for the formation of these indolic metabolites, though it did not exclude the possibile role of the ruminal protozoa in the formation of these metabolites. Later, rumen protozoa were also shown to produce mainly indoleacetate (30 to $50 \%$ of the degraded tryptophan) from Ltryptophan by means of paper chromatography as an analytical technique ${ }^{8)}$.

In terms of the prevention of acute pulmonary edema and emphysema in cattle, ionophore antibiotics such as monensin and salinomycin (SL) have been shown to have an inhibitory effect on the production of skatole by in vitro and in vivo rumen microorganisms ${ }^{10-12,15)}$, but their effects on indole production by mixed rumen microbes and on indolic compounds production by protozoa have not been examined.

The present in vitro study was conducted to confirm the production of indole and skatole from L-tryptophan by mixed rumen bacteria, mixed rumen protozoa and their combinations, and to examine the effects of SL on the production of indole and skatole from tryptophan by those microorganisms. The effects of indole and skatole on the survival of protozoa and the production of volatile fatty acids (VFA) in those microbial suspensions were also examined.

\section{Materials and Methods}

1. Rumen microbial suspensions

Rumen microorganisms were obtained from a fistulated Japanese-Saanen goat (female, 40 $\mathrm{kg}$ ) fed on a daily ration consisting of lucerne (Medicago sativa) cubes (23 $\mathrm{g}$ dry matter $/ \mathrm{kg}$ body-weight ${ }^{0.75}$ ) and concentrate feed (formula feed : alphatopbeef, Chubu-Shiryo, Japan ; $8 \mathrm{~g}$ dry matter $/ \mathrm{kg}$ body-weight ${ }^{0.75}$ ) in two equal portions given at 0900 and $1700 \mathrm{~h}$.

Rumen contents were taken before the morning feed and were strained through four layers of surgical gauze. Samples of strained rumen fluid were then poured into a separating funnel that had been gassed with $\mathrm{O}_{2}$-f ree $95 \%$ $\mathrm{N}_{2}-5 \% \quad \mathrm{CO}_{2}$. The funnel and contents were maintained at $39^{\circ} \mathrm{C}$ for up to $60 \mathrm{~min}$ to allow fine feed particles to float. Most of the lower portion was then anaerobically transferred to centrifuge tubes, cooled in ice cold water (about $4^{\circ} \mathrm{C}$ ) and centrifuged at $270 \times g$ for $3 \mathrm{~min}$. The supernatant fluid thus obtained was microscopically examined and found to be free from protozoa. Since it consisted mainly of mixed rumen bacteria, it was used for bacterial suspensions and designated "B suspension". The centrifuged pellet (mainly protozoa) was washed five times with MB 9 buffer solution $^{(6)}$ and then divided into two portions. One portion was anaerobically added to the $\mathrm{B}$ suspension at about $4 \%(\mathrm{vol} / \mathrm{vol})$ so as to 
prepare almost the same microbial densities as those original strained rumen digesta, and was used for mixed microbial suspensions of bacteria and protozoa (BP suspension). The other portion was anaerobically resuspended in MB 9 buffer solution at about $4 \%$ (vol $/ \mathrm{vol}$ ) to produce protozoal suspension ( $\mathrm{P}$ suspension). The latter always included $0.1 \mathrm{mg} / \mathrm{ml}$ each of dihydrostreptomycin sulfate and penicillin $G$ potassium to suppress the biochemical activity of contaminating bacteria.

2. Incubation and sample treatments

Microbial suspensions $(30 \mathrm{~m} l)$ were anaerobically incubated, in triplicate, in $50 \mathrm{ml}$ Erlenmeyer flasks for up to $12 \mathrm{~h}$ at $39^{\circ} \mathrm{C}$. All incubations contained $0.5 \mathrm{mg} / \mathrm{ml}$ of rice starch. L-tryptophan $(1 \mu \mathrm{mol} / \mathrm{m} l$, Wako Pure Chemical Industries Ltd., Japan), salinomycin (SL, $5 \mu \mathrm{g}$ / $m l$, Kaken Pharmaceutical Co. Ltd., Japan), indole or skatole (both dissolved in minimal volumes of ethanol with $1 \mathrm{ml}$ of the ethanol solution added to $30 \mathrm{~m} l$ incubation) were added to various incubations.

Samples $(1 \mathrm{~m} l)$ of the incubations were removed throughout the incubation periods. Some were prepared for HPLC analysis by the addition of an equal volume of $4 \%$ (wt/vol) sulfosalicylic acid, centrifugation at $27,000 \times \mathrm{g}$ for $20 \mathrm{~min}$, filtration ( $0.45 \mu \mathrm{m}$ membrane) and storage at $4^{\circ} \mathrm{C}$. Others were prepared for VFA analysis by mixing them with $1 \mathrm{~m} l \quad 10 \%$ metaphosphoric acid (in $2 \mathrm{~N} \mathrm{H}_{2} \mathrm{SO}_{4}$ ).

In order to determine prozozoal numbers, $0.5-\mathrm{m} l$ portions of the microbial suspensions were collected, mixed with $4.5 \mathrm{~m} l$ of MFS (methylgreen-formalin-salt) solution ${ }^{17)}$ and

Table 1. Effect of salinomycin (SL) on the degradation of tryptophan and production of indole and skatole by mixed rumen protozoa (P), mixed rumen bacteria (B) and their mixture (BP)

\begin{tabular}{|c|c|c|c|c|c|c|}
\hline \multirow{2}{*}{$\begin{array}{l}\text { Rumen } \\
\text { microorganisms }\end{array}$} & & \multicolumn{5}{|c|}{ Incubation time $(h)$} \\
\hline & & 0 & 3 & 6 & 9 & 12 \\
\hline \multicolumn{7}{|c|}{ Tryptophan existed (nmol/ml) } \\
\hline \multirow{2}{*}{$\mathrm{P}$ suspension } & Without & $1,025 \pm 10$ & $998 \pm 15^{b}$ & $974 \pm 6^{b}$ & $976 \pm 29^{b}$ & $958 \pm 13^{b}$ \\
\hline & With & $988 \pm 12$ & $955 \pm 12^{b}$ & $960 \pm 12^{b}$ & $941 \pm 19^{b}$ & $876 \pm 48^{c}$ \\
\hline \multirow[t]{2}{*}{ B suspension } & Without & $997 \pm 14$ & $814 \pm 11^{c}$ & $687 \pm 10^{c}$ & $492 \pm 11^{c}$ & $335 \pm 17^{d}$ \\
\hline & With & $999 \pm 13$ & $935 \pm 35^{b}$ & $903 \pm 6^{b}$ & $925 \pm 62^{b}$ & $890 \pm 13^{c}$ \\
\hline \multirow[t]{2}{*}{ BP suspension } & Without & $1,021 \pm 15$ & $766 \pm 18^{c}$ & $583 \pm 20^{c}$ & $370 \pm 22^{d}$ & $214 \pm 17^{e}$ \\
\hline & With & $978 \pm 22$ & $919 \pm 24^{b}$ & $866 \pm 9^{b}$ & $850 \pm 8^{b}$ & $843 \pm 20^{c}$ \\
\hline \multicolumn{7}{|c|}{ Indole produced $(\mathrm{nmol} / \mathrm{m} l)$ a } \\
\hline \multirow[t]{2}{*}{$P$ suspension } & Without & 0 & $14.1 \pm 1.5^{\mathrm{f}}$ & $32.2 \pm 1.6^{f}$ & $53.2 \pm 6.3^{f}$ & $62.8 \pm 1.7^{1}$ \\
\hline & With & 0 & $6.5 \pm 1.1^{8}$ & $16.7 \pm 1.3^{f}$ & $34.0 \pm 2.2^{f}$ & $117.1 \pm 23.6^{\mathrm{g}}$ \\
\hline \multirow[t]{2}{*}{$B$ suspension } & Without & 0 & $5.1 \pm 0.3^{8}$ & $4.8 \pm 0.3^{8}$ & $11.0 \pm 3.2^{\mathrm{g}}$ & $18.3 \pm 5.8^{\mathrm{h}}$ \\
\hline & With & 0 & $0^{\mathrm{h}}$ & $0^{\text {h }}$ & $0^{\mathrm{h}}$ & $0^{i}$ \\
\hline \multirow[t]{2}{*}{ BP suspension } & Without & 0 & $3.7 \pm 0.4^{\mathrm{g}}$ & $15.2 \pm 4.0^{f}$ & $22.6 \pm 1.9^{8}$ & $32.0 \pm 8.2^{h}$ \\
\hline & With & 0 & $0^{\mathrm{h}}$ & $0^{\mathrm{h}}$ & $0^{\mathrm{h}}$ & $0^{i}$ \\
\hline \multicolumn{7}{|c|}{ Skatole produced $(\mathrm{nmol} / \mathrm{m} l)^{a}$} \\
\hline \multirow[t]{2}{*}{ P suspension } & Without & 0 & 0 & $o^{j}$ & $0^{1}$ & $0^{1}$ \\
\hline & With & 0 & 0 & $0^{j}$ & $0^{1}$ & $0^{j}$ \\
\hline \multirow[t]{2}{*}{ B suspension } & Without & 0 & $5.9 \pm 1.8$ & $7.2 \pm 2.4^{k}$ & $25.4 \pm 3.9^{k}$ & $44.3 \pm 20.1^{k}$ \\
\hline & With & 0 & 0 & $0^{j}$ & $0^{1}$ & $4.8 \pm 0.7^{i}$ \\
\hline \multirow[t]{2}{*}{ BP suspension } & Without & 0 & 0 & $32.3 \pm 3.5^{1}$ & $109.1 \pm 1.1^{\prime}$ & $213.0 \pm 63.0^{1}$ \\
\hline & With & 0 & 0 & $o^{j}$ & $0^{1}$ & $13.9 \pm 0.4^{\mathrm{m}}$ \\
\hline
\end{tabular}

a Values are means $\pm \mathrm{SE}$.

$b, c, d, e, f, g, h, i$, and $i, k, l, m$ Means in the same column with different superscript differ $(P<0.01)$. 
Table 2. Effects of indole and skatole on the rate of survival (\%) of rumen protozoa in mixed protozoal (P) suspension and in mixed bacterial and protozoal (BP) suspension

\begin{tabular}{|c|c|c|c|}
\hline \multirow[b]{2}{*}{ Addition } & \multicolumn{3}{|c|}{ Incubation time (h) } \\
\hline & 0 & 3 & 6 \\
\hline \multicolumn{4}{|c|}{ In $\mathrm{P}$ suspension ${ }^{a}$} \\
\hline None & 100 & $96.2 \pm 0.2$ & $79.3 \pm 11.8$ \\
\hline Indole $\quad 2 \mathrm{mM}$ & 100 & $24.8 \pm 6.7^{b}$ & $6.9 \pm 0.7^{6}$ \\
\hline Indole $10 \mathrm{mM}$ & $14.5 \pm 1.2$ & $0^{b}$ & $0^{b}$ \\
\hline Skatole $2 \mathrm{mM}$ & $86.2 \pm 4.1^{b}$ & $9.6 \pm 0.1^{b}$ & $2.0 \pm 0.6^{b}$ \\
\hline Skatole $10 \mathrm{mM}$ & $19.8 \pm 2.1^{b}$ & $0^{b}$ & $0^{b}$ \\
\hline \multicolumn{4}{|c|}{ In BP suspension ${ }^{a}$} \\
\hline None & 100 & $91.0 \pm 3.4$ & $91.1 \pm 3.9$ \\
\hline Indole & 100 & $88.6 \pm 6.3^{b}$ & $86.2 \pm 4.7^{b}$ \\
\hline Indole $10 \mathrm{mM}$ & $81.5 \pm 7.5^{b}$ & $13.2 \pm 1.2^{6}$ & $0.8 \pm 0.7^{b}$ \\
\hline Skatole $2 \mathrm{mM}$ & 100 & $91.5 \pm 1.8^{b}$ & $71.5 \pm 10.5^{b}$ \\
\hline Skatole $10 \mathrm{mM}$ & $80.9 \pm 20.8^{b}$ & $6.4 \pm 3.5^{b}$ & $0^{b}$ \\
\hline
\end{tabular}

a $V$ alues are means $\pm S E$.

"Significantly different from control $(\mathrm{P}<0.01)$.

kept at room temperature.

3. Analytical methods

Analyses of tryptophan, indole and skatole were carried out by $\mathrm{HPLC}^{14)}$. VFA concentrations were measured by gas chromatography ${ }^{13)}$. Rumen protozoa were counted with the aid of a Fuchs-Rosenthal hemacytometer. Statistically significant differences between mean values were tested for via the Student's t-test.

\section{Results}

\section{Degradation of tryptophan}

Table 1 shows that in P suspensions $193 \%$ of Entodinium, $6 \%$ of Diplodiniinae and $1 \%$ of Isotrichidae), the addition of SL increased the degradation of tryptophan from $6.5 \%$ of the amount added to $11.3 \%$ during a $12-\mathrm{h}$ incubation. By contrast, in $\mathrm{B}$ and $\mathrm{BP}$ suspensions without SL, 66.4 and $79.0 \%$ respectively of the tryptophan was degraded, whereas when SL was added these values were decreased to only 10.9 and $13.8 \%$.

\section{Production of indole}

Table 1 also shows that in $\mathrm{P}$ suspensions without SL, indole was produced in significantly larger concentrations than in $\mathrm{B}$ and $\mathrm{BP}$
Table 3. Effects of indole and skatole on the production of total volatile fatty acids $(\mu \mathrm{mol} / \mathrm{ml})$ by mixed rumen protozoa $(P)$, mixed rumen bacteria (B) and their mixture (BP)

\begin{tabular}{|c|c|c|}
\hline \multirow[b]{2}{*}{ Addition } & \multicolumn{2}{|c|}{ Incubation time (h) } \\
\hline & 3 & 6 \\
\hline \multicolumn{3}{|c|}{ In $\mathrm{P}$ suspension ${ }^{a}$} \\
\hline None & $4.68 \pm 0.10$ & $7.62 \pm 0.62$ \\
\hline Indole $\quad 2 \mathrm{mM}$ & $2.04 \pm 0.09^{b}$ & $2.49 \pm 0.31^{b}$ \\
\hline Indole $10 \mathrm{mM}$ & $0^{b}$ & $\mathrm{O}^{\mathrm{b}}$ \\
\hline Skatole $2 \mathrm{mM}$ & $1.19 \pm 0.60^{b}$ & $1.39 \pm 1.13^{b}$ \\
\hline \multicolumn{2}{|c|}{ In B suspension ${ }^{a}$} & $\mathrm{O}^{\mathrm{b}}$ \\
\hline None & $4.36 \pm 0.54$ & $7.46 \pm 0.97$ \\
\hline Indole & $5.59 \pm 0.71$ & $8.00 \pm 0.64$ \\
\hline Indole $10 \mathrm{mM}$ & $1.45 \pm 0.39^{b}$ & $0.88 \pm 0.51^{b}$ \\
\hline Skatole $2 \mathrm{mM}$ & $5.41 \pm 1.28$ & $8.71 \pm 3.48$ \\
\hline \multicolumn{2}{|c|}{ In BP suspension ${ }^{2}$} & $0.83 \pm 0.18^{b}$ \\
\hline None & $6.87 \pm 3.02$ & $14.28 \pm 2.76$ \\
\hline Indole & $8.41 \pm 1.23$ & $28.07 \pm 2.50$ \\
\hline Indole $10 \mathrm{mM}$ & $3.01 \pm 1.77^{b}$ & $1.86 \pm 0.36^{b}$ \\
\hline Skatole $2 \mathrm{mM}$ & $9.25 \pm 2.35$ & $16.46 \pm 2.06$ \\
\hline Skatole $10 \mathrm{mM}$ & $1.63 \pm 1.53^{\mathrm{b}}$ & $3.15 \pm 2.46^{b}$ \\
\hline
\end{tabular}

values are means $\pm S E$.

${ }^{b}$ Significantly different from control $(P<0.01)$. 
Table 4. Effects of indole and skatole on the molar percentages of volatile fatty acids produced in the mixed rumen bacterial (B) suspension and in the mixed bacterial and rotozoal (BP) suspension after incubation for $6 \mathrm{~h}$

\begin{tabular}{|c|c|c|c|c|}
\hline \multirow[b]{2}{*}{ Addition } & & \multicolumn{3}{|c|}{ Molar percentage $(\%)$} \\
\hline & & Acetate & Propionate & Butyrate \\
\hline \multicolumn{5}{|c|}{ In $\mathrm{B}$ suspension ${ }^{\mathrm{a}}$} \\
\hline None & & $58.5 \pm 14.7$ & $29.3 \pm 12.1$ & $8.2 \pm 1.6$ \\
\hline Indole & $1 \mathrm{mM}$ & $62.9 \pm 8.3$ & $24.9 \pm 9.6$ & $7.5 \pm 2.2$ \\
\hline Indole & $2 \mathrm{mM}$ & $59.0 \pm 12.7$ & $28.2 \pm 12.2$ & $7.7 \pm 0.5$ \\
\hline Indole & $4 \mathrm{mM}$ & $62.0 \pm 9.5$ & $25.2 \pm 8.9$ & $8.1 \pm 0.8$ \\
\hline Skatole & $1 \mathrm{mM}$ & $65.4 \pm 9.7$ & $23.4 \pm 8.7$ & $7.2 \pm 0.9$ \\
\hline Skatole & $2 \mathrm{mM}$ & $64.7 \pm 10.2$ & $23.7 \pm 10.3$ & $8.6 \pm 0.7$ \\
\hline Skatole & $4 \mathrm{mM}$ & $78.9 \pm 22.8$ & $6.9 \pm 9.5$ & $9.2 \pm 11.9$ \\
\hline \multicolumn{5}{|c|}{ In $\mathrm{BP}$ suspension ${ }^{\mathrm{a}}$} \\
\hline None & & $61.1 \pm 2.5$ & $17.0 \pm 3.1$ & $14.1 \pm 0.9$ \\
\hline Indole & $1 \mathrm{mM}$ & $55.8 \pm 4.5$ & $18.2 \pm 2.8$ & $15.5 \pm 1.0$ \\
\hline Indole & $2 \mathrm{mM}$ & $54.7 \pm 0.8^{b}$ & $18.3 \pm 1.5$ & $15.7 \pm 2.0$ \\
\hline Indole & $4 \mathrm{mM}$ & $50.1 \pm 2.5^{b}$ & $21.0 \pm 2.1$ & $16.0 \pm 1.9$ \\
\hline Skatole & $1 \mathrm{mM}$ & $53.0 \pm 4.5^{b}$ & $18.5 \pm 2.6$ & $16.8 \pm 3.1$ \\
\hline Skatole & $2 \mathrm{mM}$ & $50.4 \pm 0.6^{b}$ & $21.5 \pm 2.9$ & $16.7 \pm 1.6$ \\
\hline Skatole & $4 \mathrm{mM}$ & $50.6 \pm 6.8^{b}$ & $21.4 \pm 3.5$ & $16.8 \pm 3.2$ \\
\hline
\end{tabular}

a Values are means \pm SE.

${ }^{b}$ Significantly different from control $(P<0.01)$.

suspensions. The effect of adding SL was to increase the indole production after $12 \mathrm{~h}$ in $\mathrm{P}$ suspensions, but to inhibit completely its production in both $\mathrm{B}$ and $\mathrm{BP}$ suspensions.

3. Production of skatole

$P$ suspensions, either with or without SL, produced no skatole from tryptophan during 12-h incubation periods (Table 1). By contrast, $\mathrm{B}$ and $\mathrm{BP}$ suspensions produced as much as 44.3 and $213.0 \mathrm{nmol}$ skatole per $\mathrm{ml}$ respectively in $12 \mathrm{~h}$. However, when SL was added to these suspensions, skatole production was completely repressed for $9 \mathrm{~h}$ and was only 4.8 and $13.9 \mathrm{nmol} / \mathrm{m} l$ after $12 \mathrm{~h}$ of incubation.

4. Effects of indole and skatole on the survival of rumen protozoa

These results are shown in Table 2. In $\mathrm{P}$ suspensions, $2 \mathrm{mM}$ indole destroyed $75 \%$ protozoa, whereas $10 \mathrm{mM}$ completely annihilated them after $3 \mathrm{~h}$. Skatole produced a similar pattern. In BP suspensions, the effects were similar, though both $2 \mathrm{mM}$ indole and skatole appeared to exert a less toxic effect on the protozoa.

5. Effects of indole and skatole on the production of VFA

Results in Table 3 show that in $\mathrm{P}$ suspensions, $2 \mathrm{mM}$ indole and skatole reduced the total VFA production at $6 \mathrm{~h}$ to 32.7 and $18.2 \%$ of the control value, respectively. Ten $\mathrm{mM}$ indole and skatole completely depressed VFA production. In $B$ suspensions, $2 \mathrm{mM}$ indole and skatole tended to enhance VFA production, while $10 \mathrm{mM}$ indole and skatole strictly depressed VFA production. In BP suspensions, the control values of VFA production over a $6 \mathrm{~h}$ period were about two times higher than those in $\mathrm{P}$ and $\mathrm{B}$ suspensions. In this case, $2 \mathrm{mM}$ indole and skatole also tended to enhance the VFA productions. Both $10 \mathrm{mM}$ indole and skatole severely decreased VFA production.

Table 4 shows the effects of indole and skatole on the molar percentages of VFA produced. In B suspensions, indole and skatole 
tended to decrease the molar percentages of propionate and to increase those of acetate, when compared with the control values. In BP suspensions, however, both indole and skatole tended to increase the molar percentages of propionate and butyrate, and to decrease the percentage of acetate, when compared with the control values.

\section{Discussion}

1. Effects of salinomycin on the production of indole and skatole

In $\mathrm{P}$ suspensions without $\mathrm{SL}, 67 \mathrm{nmol} / \mathrm{m} l$ (6.5\%) of the added tryptophan was degraded and $62.8 \mathrm{nmol} / \mathrm{m} l$ of indole (equivalent to about $6.1 \%$ of the added tryptophan) was produced in the medium during a 12 -h incubation period (Table 1). Thus the molar amount of the degraded tryptophan and that of the produced indole were proximate. An intriguing feature was that indole production in $\mathrm{P}$ suspensions was significantly higher $(\mathrm{P}<0.01)$ than those in B and BP suspensions. Skatole was not produced in $\mathrm{P}$ suspensions. As described in the "Introduction", YoKOYAMA and CARLSON $^{18)}$ showed that $8 \%$ of the radioactivity of ${ }^{14} \mathrm{C}$-labelled tryptophan was incorporated into indoleacetate, $3 \%$ into indole and $0.1 \%$ into skatole, after incubation of a crude preparation of rumen protozoa for $24 \mathrm{~h}$. Another report ${ }^{8)}$ also showed that a main metabolite of L-tryptophan by rumen protozoa was indoleacetate. In the present experiments, indoleacetate was not determined, but since the molar amount of the degraded tryptophan was almost equal to that of the produced indole, indole seemed to be the only product or at least a principal metabolite of rumen protozoa, which is different from previous result obtained by other investigators ${ }^{8,18)}$.

In $\mathrm{P}$ suspensions with $\mathrm{SL}$, indole production tended to be lower than in $\mathrm{P}$ suspensions without SL during a 9-h incubation period, but at $12 \mathrm{~h}$, indole production with $\mathrm{SL}$ was significantly $(\mathrm{P}<0.01)$ (1.86 times) higher than that without SL (Table 1). Thus SL did not severely affect indole production by rumen protozoa and in a later incubation period it stimulated indole production by protozoa, which was different from the inhibitory effect of ionophores on indole and skatole production by rumen bacteria (see Table 1 and References 10 and 11). This is the first observation of the effect of SL on the tryptophan metabolism by rumen protozoa, as far as we are aware. Though we can not speculate with confidence how SL acts on the production of indole from tryptophan by protozoa, SL appears to stimulate the transport of tryptophan into the cells of protozoa, or to activate an enzyme to produce indole. However the latter idea is improbable, because SL completely inhibited the production of indole in $\mathrm{B}$ and $\mathrm{BP}$ suspensions.

In B suspensions without SL, 1.84 and $4.44 \%$ of the added tryptophan were converted to indole and skatole, respectively, after incubation for $12 \mathrm{~h}$, while the degraded tryptophan at $12 \mathrm{~h}$ was $66.4 \%$ of the added tryptophan (Table 1). Thus about $60 \%$ of the added tryptophan could be converted to other metabolites among which indoleacetate could be a main produdt, because skatole has been revealed to be produced from tryptophan by indoleacetate as an intermediate ${ }^{18)}$, though indoleacetate was not determined in the present experiment. These results showed a tendency similar to the results of the previous report by other investigators ${ }^{18)}$ in which indoleacetate, indole and skatole were 50,4 and $13 \%$ of the initial molar amount of tryptophan, respectively, after incubation for $24 \mathrm{~h}$. In B suspensions, SL completely inhibited the indole production during a $12-\mathrm{h}$ incubation period and severely inhibited skatole production, being only $0.48 \%$ of the added tryptophan at $12 \mathrm{~h}$. However, the degraded tryptophan was $10.9 \%$ of the added tryptophan, so about $10 \%$ should be other metabolies like indoleacetate. These results suggest that SL inhibited at the level 
of tryptophan conversion to indoleacetate as well as the description by HAMMOND and CARLSON $^{11)}$ and at the same time at the level of indoleacetate conversion to skatole.

In BP suspensions without SL, 3.13 and $20.9 \%$ of the added tryptophan were converted to indole and skatole, respectively, after incubation for $12 \mathrm{~h}$, while the degraded tryptophan at $12 \mathrm{~h}$ was $79.0 \%$ of the added tryptophan (Table 1). Therefore, about $55 \%$ of the added tryptophan could be other forms of metabolites (maybe mainly indoleacetate). In the experiment by YOKOYAMA and CARLSON ${ }^{18)}$, 7 and $39 \%$ of the added radioactivity of ${ }^{14} \mathrm{C}-$ tryptophan were incorporated into iodole and skatole after incubation for $24 \mathrm{~h}$, and these results had a tendency silmilar to the present experiment, but in their experiment only $4 \%$ of the added radioactivity incorporated into indoleacetate after incubation for $24 \mathrm{~h}$.

A notable point was that the amount of skatole $(213.0 \mathrm{nmol} / \mathrm{m} l)$ produced in BP supensions without SL during a $12-\mathrm{h}$ incubation period was significantly $(\mathrm{P}<0.01)$ (ca. 5 -fold) higher than that $(44.3 \mathrm{nmol} / \mathrm{ml})$ produced in $B$ suspensions without SL during the same incubation period, despite the fact that protozoa never produced skatole in the present experiment. According to the report of YoKoY AMA and CARLSON ${ }^{18)}$, this point was also true, namely the percentage of skatole produced in mixed suspensions of protozoa and bacteria was about 3-fold higher than that produced in only bacterial suspensions. Complicated interactions between protozoa and bacteria probably resulted in a value more than an arithmetic or mechanical sum of single values (metabolic activities) of protozoa and bacteria. The existence of protozoa in the rumen microbial ecosystem might stimulate in some way, skatole production by bacteria. Ecological points like this should be analyzed in near future.

In BP suspension with SL (Table 1), indole was not produced during a $12-\mathrm{h}$ incubation period. Skatole was not produced till $9 \mathrm{~h}$, though at $12 \mathrm{~h}$ it was produced by $1.42 \%$ of the added tryptophan. Since the degraded tryptophan was $13.8 \%$ of the added tryptophan, about $12 \%$ of the added tryptophan was thought to be other metabolites like indoleacetate. These results also suggest that SL inhibited both at the level of tryptophan conversion to indoleacetate and at the level of indoleacetate conversion to skatole, as mentioned for $B$ suspensions.

Thus in $\mathrm{B}$ and $\mathrm{BP}$ suspensions, $\mathrm{SL}$ was confirmed to be effective in inhibiting the production of metabolites like indoleacetate, skatole and indole. SL probably inhibited the transport of tryptophan into bacterial cells.

2. Effects of indole and skatole on protozoa and VFA production

The disruptive effects of indole and skatole on rumen protozoa were shown firstly by EAdie and OXFORD ${ }^{7)}$ and the nature of indole was applied for preparing some enzymes of protozoa themselves, because it was selective for protozoa and any associated bacteria were not broken ${ }^{1,23}$. The concentration of indole they used for the disruption of protozoa was about $0.1 \%$ (about $8.5 \mathrm{mM}$ ). In the present experiment, $10 \mathrm{mM}$ indole and skatole also destroyed almost all protozoal cells in $\mathrm{P}$ suspensions immediately after it was added (Table 2).

It is of interest that in BP suspensions, both indole and skatole significantly $(\mathrm{P}<0.01)$ lowered the molar percentage of acetate and had tendencies to enhance the molar percentages of propionate and butyrate (Table 4). Indole and skatole at this level might shift slightly the flow of electrons more in the direction of propionate and butyrate as electron sink products. As far as we are aware, these observations have never been reported.

\section{Acknowledgement}

The authors are grateful to Dr. H. OGAwA, 
Onodera, Uedia, Nagasawa, Okuuchi, Chaen, Mieno and Kudo

Associate Professor of Miyazaki University, for inserting permanent rumen fistula into a goat, and to Dr. J.R. LING, University College of Wales, Aberystwyth, for valuable comments. Dr. Ling stayed at ONODERA's laboratory, Miyazaki University, for three months in 1989 as an invited Professor sponsored by Monbusho/British Council. Part of this study was financially supported by Showa Denko Co., Ltd. We also appreciate Kaken Pharmaceutical Co., Ltd. for donating salinomycin.

This paper is a part of the Master's Thesis of H. UEDA submitued to Miyazaki University, 1988 .

\section{References}

1) Bailey, R.W. and B.H. Howard, Preparation of enzymes from rumen protozoa by indole disintegration. Arch. Biochem. Biophys., 99: 299-303. 1962.

2) Bailey, R.W. and G.B. Russell, Disruption of protozoa by indole and related compounds. Nature, 208: 1001-1002. 1965.

3) Boyd, W.L. and H.C. Lichstern, The effect of carbohydrates on the tryptophanase activity of bacteria. J. Bacteriol., 69: 584589. 1955.

4) Burns, R.O. and R.D. Demoss, Properties of tryptophanase from Escherichia coli. Biochim. Biophys. Acta, 65 : 233-244. 1962.

5) Carlson, J.R., M.T. Yokoyama and E.O. Dikinson, Induction of pulmonary edema and emphysema in cattle and goats with 3-methylindole. Science, 176 : 298-299. 1972.

6) Cowell, J.L., K. Moser and R.D. Demoss, Tryptophanase from Aeromonas liquefaciens. Purification, molecular weight and some chemical, catalytic and immunochemical properties. Biochim. Biophys. Acta, 315: 449-463. 1973.

7) EADIE, J.M. and A.E. OXFoRD, A remarkable disintegrative effect of skatole upon certain rumen ciliate protozoa, Nature, 174: 973. 1954.

8) Endo, M. and M. Kandatsu, Degradation of tryptophan by rumen ciliate protozoa, Nippon Nogeikagaku Kaishi, 55 : 817-819.
1981.

9) Evans, W.C., W.C.R. Handley and F.C. HAPPOLD, The tryptophanase-tryptophan reaction. 5. Possible mechanisms for the inhibition of indole production by glucose in cultures of $B$. coli. Biochem. J., 36 : 311-318. 1942.

10) Hammond, A.C., J.R. CARlson and R.G. BREEzE, Monensin and the prevention of tryptophan-induced acute bovine pulmonary edema and emphysema. Science, 201 : 153-155. 1978.

11) Hammond, A.C. and J.R. Carlson, Inhibition of ruminal degradation of L-tryptophan to 3-methylindole, in vitro. J. Anim. Sci., 51 : 207-214. 1980.

12) Honeyfield, D.C., J.R. Carlson, M.R. NOCERINI and R.G. BREEZE, Duration of inhibition of 3-methylindole production by monensin. J. Anim. Sci., 60 : 226-231. 1985.

13) Kageyama, K., H. Mori and K. Sato, Simultaneous determination of volatile fatty acids and lactic acid in silage by gas chromatography. Jpn. J. Zootech. Sci., 44: 465-469. 1973.

14) Nagasawa, T., H. Ueda and R. Onodera, Rapid determination of tryptophan, indole and skatole in rumen fluid by HPLC. Jpn. J. Zootech. Sci., 59: 93-84. 1988.

15) Nocerini, M.R., D.C. Honeyfield, J.R. CARLSON and R.G. BreEze, Reduction of 3-methylindole production and prevention of acute bovine pulmonary edema and emphysema with lasalocid. J. Anim. Sci., 60 : 232-238. 1985.

16) Onodera, R. and C. Henderson, Growth factors of bacterial origin for the culture of the rumen oligotrich protozoon, Entodinium caudatum. J. Appl. Bacteriol., 48: 125-134. 1980.

17) Onodera, R., H. Yamaguchi, C. Eguchi and M. KANDATSU, Limits of survival of the mingled rumen bacteria in the washed cell suspension of rumen ciliate protozoa. Agric. Biol. Chem,, 41 : 2465-2466. 1977.

18) Yokoyama, M.T. and J.R. CARLson, Dissimilation of tryptophan and related indolic compounds by ruminal microorganisms in vitro. Appl. Microbiol., 27 : 540-548. 1974. 
In vitro におけるルーメンプロトゾアおよびバクテリアによる

トリプトファン代謝 : インドールおよびスカトールの

生成ならびにそれらの化合物がプロトゾアの生存

および VFA の生成に及ぼす影響

小野寺良次 $\cdot$ 上田 寛・長澤孝志・奥内勝也
茶圓茂広 $^{* *} \cdot$ 三重野通啓 ${ }^{* *} \cdot$ 工藤英彦

宮崎大学農学部，宮崎市 889-21

現所属 : *大鵬製薬工業(株), 徳島市 771-01

**昭和電工(株), 東京都港区 105

***科研製楽(株)，東京都中央区 103

In vitro でのルーメンプロトゾア (P 愳濁液)，ルーメンバクテリア（B 䀣濁液）およびそれらの湿 合䀣濁䘸（BP 眯濁液）に上る L-トリプトファン（Trp）からのインドール（Ind）およびスカトール (Skt) の生成を確認するとともに，これらの微生物㲘濁液によるTrp からの Ind および Skt 生成に 及ぼすサリノマイシン（SL）の影響を検討する目的で本研究を計画した。また，同時に，Ind および Skt がプロトゾアの生存および上記の各種微生物縣濁液中における揮発性脂肪酸（VFA）の生成に及 ぼす影響も検討した，ルーメン微生物はフフィスチュラ装着山羊から採取した，その結果，P䀣濁液 は，12 時間の培養中に Trp 加ら Ind のみを生成した. SL は P 惖濁液における Ind の生成を促進し

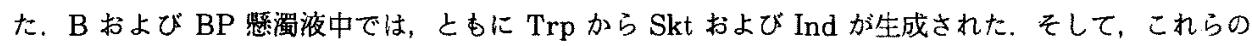
生成は SL によりほぼ完全に抑制された，低謴度 $(2 \mathrm{mM})$ の Ind および Skt 存在下では，BP 惩濁

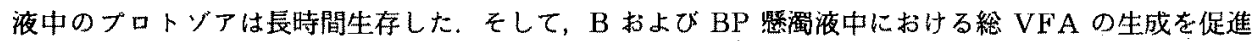
し，また，BP 奬濁液中におけるプロピオン酸と酪酸のモル百分率を增加させた．

日畜会報， $63(1): 23-31,1992$ 